\title{
The International Information Consultant: A Primer on Avoiding Potholes, Perils, and Pitfalls
}

\author{
CATHERINE LEMMER*
}

\begin{abstract}
Consultants are retained to assist libraries in identifying, designing, and implementing solutions to a wide variety of strategic, management, operational, and human resources issues. The goal of the library-consultant relationship is to improve the operations of the organization. Although often unrecognized as such, law librarians are natural consultants. Librarians are problem solvers, and as such develop and use many of the same skills as consultants in their everyday roles in the law library.

For those versatile librarians skilled in change management and interested in pursuing these challenging professional opportunities, this article discusses best practices for library consultants and provides advice on how to avoid pitfalls in the context of an international case study. Part I of the article provides an introduction to professional consulting. Part II discusses the author's case study, a six-month fellowship with the Legal Resources Centre of South Africa. Part III then concludes the article with an articulation of the skills and talents exhibited by successful consultants to enable interested readers to better understand if consulting is an opportunity matched to their professional interests and skills.
\end{abstract}

\section{Introduction}

Change is the only constant in today's law library environment. In this setting, library directors and librarians struggle to answer one basic question: What should we be tomorrow that is more effective and more efficient than yesterday so that we remain vital to our users? ${ }^{1}$ We instinctively know that after all the budget. reductions and organizational restructuring we must be

* (2014 Catherine A. Lemmer. The author is Head of Information Services, Ruth Lilly Law Library, Indiana University Robert H. McKinney School of Law, Indianapolis, Indiana.

${ }^{1}$ Edward G. Verlander, The Practice of Professional Consulting, xvi (2012). 
"something better" than simply a less expensive version of our former self. ${ }^{2}$ But what is that "something better"? For assistance in answering this question law libraries often seek guidance from consultants.

Consultants are retained to assist libraries in identifying, designing, and implementing solutions to a wide variety of strategic, management, operational, and human resources issues. The goal of the library-consultant relationship is to improve the operations of the organization. The term and length of the relationship depends on the problem or issue to be addressed and resolved. Consultants in their role as designated problem solvers possess an identifiable skill set and are guided by a prescribed set of professional principles and standards. ${ }^{3}$

Although often unrecognized as such, law librarians are natural consultants. ${ }^{4}$ Librarians are problem solvers, and as such develop and use many of the same skills as consultants in their everyday roles in the law library. Similarly, librarians' actions are guided by a set of professional principles and standards and carried out with the intent to improve the operations of the institution.

In summary, change creates both external and internal professional consulting opportunities. A consultant, whether internal or external, is charged with solving a problem on behalf of the library to improve the operations of the library. During the process the consultant must balance and negotiate many competing interests and stakeholders. Failure to successfully do so may result in unfilled expectations and disappointment on the part of the library in an environment where there is little tolerance for error. For those versatile librarians skilled in change management and interested in pursuing these challenging professional opportunities, this article discusses best practices for library consultants and provides advice on how to avoid pitfalls in the context of an international case study. Part I of the article provides an introduction to professional consulting. Part II discusses the author's case study, a six-month fellowship with the Legal Resources Centre of South Africa. Part III then concludes the article with an articulation of the skills and talents exhibited by successful consultants to enable interested readers to better understand if consulting is an opportunity matched to their professional interests and skills.

\footnotetext{
${ }^{2}$ Catherine A. Lemmer, A view from the flip side: Using the "inverted classroom" to enhance the legal information literacy of the international LL.M. student, 105 LAW LIBR. J. 461, 491(2013).

${ }^{3}$ Standards for conduct have been adopted by a number of professional organizations, including the, Institute of Management Consultants (IMC), Academy of Professional Consultants and Advisors (APCA), European Federation of Management Consultancies Associations (FEACO), and International Council of Management Consultant Institutes (ICMCI).

${ }^{4}$ Wendi Arant Kasper \& Wyoma vanDuinkerken, Other Duties as Assigned: Internal Consultants in Academic Libraries, 40 J. ACAD. LIBR. 1 (2014).
} 


\section{Part I: Introduction to Professional Consulting}

\section{A. Professional Consulting Defined}

Consulting is an old profession that continues to evolve to meet the needs of today's institutions. Stryker notes that although consulting as we know it in the organizational sense has been continuously practiced from about 1870 , the "ability to recognize and diagnose issues in an environment of authority and influence goes back to the beginning of Western Civilization." A consultant's work may vary from executive coaching to strategic planning to change management restructuring. The exact nature and type of the work is limited only by the ever evolving and changing needs of the client. In short, the profession continues to evolve because clients have new and evolving problems and unmet needs.

But what do consultants do? Stryker defines consulting as an "assignment in which a consultant and a client seek to resolve the client's organizational issue using a specified process." He draws this definition from an underlying understanding that consultants, unlike other professional advisors such as lawyers, teachers, or accountants, seek to "resolve issues of a one-shot, interdisciplinary nature through a continuous, short-term arrangement." The goal of the client-consultant arrangement is "to provide responsive and accurate aid for resolving [the] particular issue." ${ }^{\prime 8}$.The result of a successful arrangement is the resolution of the particular identified issue. Resolution in this context means change occurs in the structure or operations of the organization. Consultants are thus the change agents driving these changes. ${ }^{9}$

Verlander similarly advocates that consultants serve as change agents. ${ }^{10}$ Consultants are retained when someone within the library or organization identifies an issue that requires outside ${ }^{11}$ assistance to resolve. Once retained, the consultant first evaluates and assesses the client's situation with a fresh perspective, free from the limits of institutional culture or politics. ${ }^{12}$ From this evaluation and assessment, the consultant develops a set of recommendations to

\footnotetext{
${ }^{5}$ Steven C. Stryker, Principles and Practices of Professional Consulting 6 (2011).

${ }^{6} I d$, at 3.

${ }^{7} I d$.

${ }^{8} I d$.

${ }^{9} \mathrm{Id}$.

${ }^{10}$ Verlander, supra note 2, at xvi.

11 Outside can mean external to the organization or simply external to the particular team or department.

12 IRENE WORMELL, ANNIE JOAN OLESEN \& GÁBOR MTKULÁs, INFORMATION Consulting: Guide to Good Practice 117 (2011).
} 
address and resolve the identified issue. Depending on the nature of the consulting relationship, the consultant may stay with the organization through the implementation of the agreed upon recommendations. It is in this series of steps, the "asking of the right questions, identifying relevant issues, gathering and analyzing the facts, developing a plan of implementation, searching for solutions, and advising on their implementation," that consultants emerge as change agents ${ }^{13}$

In summary, consultants function as change agents in that they are retained on a short-term or limited basis to assess and resolve a specific problematic situation in an institution or organization. Since the consultant is not directly involved or affected by the situation, he or she is able to develop a set of recommendations uninhibited by internal constraints and preconceived ideas of the best solution. At all times, the goal of the process is to resolve the situation in a manner that improves (changes) the functioning of the organization's operations. As we will see in the next section, functioning as a change agent requires highly developed "human" skills in addition to the requisite technical skills.

\section{B. Who Are You and Why Are You Here?}

There is any number of negative connotations associated with consultants. Townsend advised that in the library context consultants, "waste time, cost money, demoralize and distract your best people, and don't solve problems. They are people who borrow your watch to tell you what time it is and then walk off with it."14 Given these negative perceptions, why do libraries and other organizations continue to retain consultants?

Organizations use consultants for three important reasons. First, because consultants often present a less expensive means of acquiring just-in-time needed expertise. Environmental changes may require short-term, new, or specialized expertise to develop a custom-made solution. In this case, it is too costly for the organization to keep on staff the full range of skills needed. ${ }^{15}$ Second, consultants arrive in a particular "time and place" in the organization's life span. ${ }^{16}$ As such they bring a fresh perspective because they are not hindered by institutional history, internal politics, or an inability to see beyond the current crisis. Last, consultants are used as communication channels to promote and sell an idea. Consultants are particularly useful if there are internal personal and

\footnotetext{
${ }^{13}$ Verlander, supra note 2, at xvi.

${ }^{14}$ Joseph Green, The Ideal Consultant, LIBR. J. Feb.15, @133 (1989) citing Robert Townsend, Up the Organization. FAWCETT @ 86 (1970).

${ }^{15}$ Wormell, Olesen \& Mikulás, supra note 13, at 6 and 117-118.

${ }^{16}$ Id.
} 
organizational barriers that prevent a good idea from being heard and implemented. ${ }^{1718}$

Once retained, how do consultants go about accomplishing their work? At the outset it is important to recognize the difference between a consultant and a manager and/or administrator within the organization. Although the core work of both managers and consultants is problem-solving and the methods and approaches they use in the work place are similar, there is one important functional difference. ${ }^{19}$ Unlike a manager that has control and responsibility for action, a consultant has influence but no direct power to bring about change. ${ }^{20}$

Verlander deepens the distinction by identifying the differing motivations and tactics of consultants and managers/administrators. Consultants (i) "think about being in service to others and what is best for the organization" rather than personal gain; (ii) "recommend solutions and wait for client managers to decide what they want to pursue;" (iii) help clients "decide for themselves; they never decide for the client;" and (iv) "think contextually, always considering the bigger picture when examining problems." ${ }^{\text {21 }}$

In summary, professional consultants, despite negative perceptions, bring value to an organization. In anticipating and measuring the value of a consultant, it is important to understand that the role of the consultant is one of influence rather than responsibility. In exercising his or her influence, the consultant focuses on achieving a resolution measured by what is best for the institution rather than his or her own personal career. A consultant is able to focus in this manner, because he or she is unencumbered by the institution's internal politics and structures.

\section{What Is the Work?}

The work of the consultant is often described as and reduced to a linear process model: identify the problem, identify the cause, design the solution,

\footnotetext{
${ }^{17} I d$.

${ }^{18}$ The third reason may be the most important for libraries attempting to institute new programs or processes. As vanDuinkerken and Mosley note in their work "It is an unfortunate aspect of the librarian profession that it is sometimes difficult for individuals to let past issues go by the wayside ... [T] here often seems to be a tendency to remember in perpetuity decisions and mistakes one made in the past and refuse to acknowledge that leaders grow, develop, and improve their skills over time." WYOMA VANDUINKERKEN \& PIXEY ANNE Mosley, The Challenge of Library MaNAGEMENT: LEADING WITH EMOTIONAL ENGAGEMENT 117(2011).

${ }^{19}$ Verlander supra note 2, at 11.

${ }^{20}$ Peter Block, Flawless Consulting, A gutde to Getting Your Expertise USED 2(2011).

${ }^{21}$ Verlander, supra note 2, at 11.
} 
implement the solution, and exit the organization leaving behind great love and affection (see illustration 1, below).

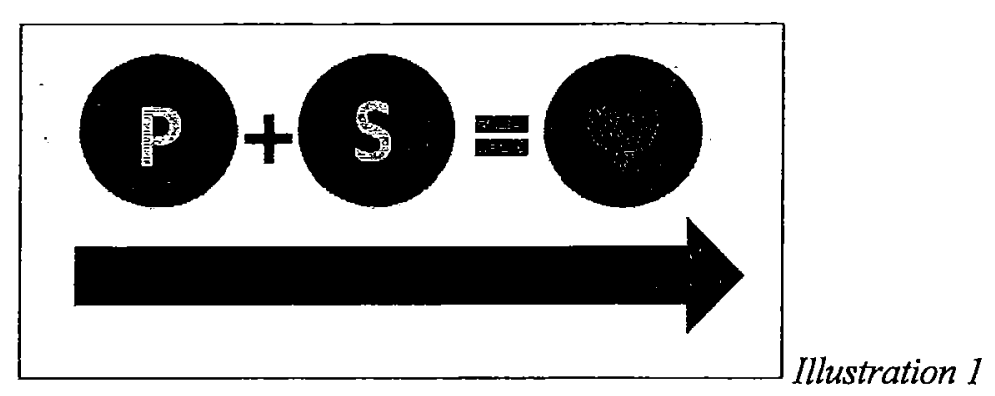

This is in part because the work is organized with project management concepts: a defined project, including deliverables, which has a prescribed start and end date. However, this simplification hides what Verlander warns will become "messy, confusing, and ambiguous" once the human element is introduced. ${ }^{22}$ As this section discusses, there are a number of mechanisms (structures) to properly manage the messy human element of professional consulting to prevent the project from being derailed.

The successful consulting arrangement follows a series of prescribed steps. The first step is identification of the project, the issue to be resolved. Although this step usually happens when someone within the organization acknowledges an issue and decides to seek outside assistance to resolve the issue, there are situations in which a consultant will be brought in to identify the organizational issue. In these circumstances, the same or a different consultant will then follow through the remaining steps to resolve the issue.

Each consultancy opportunity is unique in that the consultant is retained to address a specific issue or situation. The issue or situation will determine the nature of the consultancy: that is, whether it is tactical or strategic. Wormell and her co-authors bave identified nine unique consultancy types based on the nature of the project. These types include:

- employee substitute

- specialist

- expert advisor

- the old hand

- fixer

- creative designer

- architect or builder

- facilitator

\footnotetext{
${ }^{22}$ Verlander, supra note 2, at 52.
} 
- leader $^{23}$

Each type of consultancy identified incorporates a different scope and set of duties. For example, the "old hand" is expected to bring experience and contacts to the client and the work may be tactical or strategic. ${ }^{24}$ The "leader" consultancy brings an expectation that the consultant will be able to work independently to develop and implement strategic plans to move the organization forward. $^{25}$

The first step is an initial discussion between the consultant and the organization suggests the type of consultant arrangement that is desired or needed. However, this initial discussion is a snapshot based on one or a few opinions within the organization. The actual identification of the problem by the consultant involves listening and observing. In many instances, individuals within the organization are too close to the problem to properly diagnose what is happening and why or they may have opinions about how best to solve the problem. These are likely to be the same individuals who invite a consultant in to solve "the problem" which may turn out not to be the problem at all. It is likely the nature or type of consultancy will evolve or morph across the possible types as the project is better defined. Further research is typically needed to ensure the "real" problem has been identified and only then will the exact nature of the consultancy be determined.

The second step is to gain a full understanding of the situation and develop proposed solutions. This is the interactive and interpersonal stage during which the consultant engages with all the parties involved to gather information and gain a full understanding of the issue. In a perfect world, all the parties have been fully informed and are on board. There is never a perfect world. This step is also important because it provides the consultant with an opportunity to assess the organizational culture, measure resistance, and begin to build rapport with the many stakeholders. In other words, move closer to that perfect world ideal.

The third step is the creation of the paper trail. After a full examination of the situation and the development of proposed solutions, the plan must be properly documented in painstaking project management level detail. Specific guidelines for defining and documenting the consultant process in libraries were developed in 1984 by the British Library Association. ${ }^{26}$ These guidelines, still pertinent and useful today, sought to establish a framework to identify and protect the interests of both the consultant and the library.

\footnotetext{
${ }^{23}$ Wormell, Olesen \& Mikulás, supra note 13, at 7-10.

${ }^{24}$ Id.

${ }^{25} \mathrm{Id}$.

${ }^{26}$ Guidelines for Consultants Working in Librarianship and Information Science, 88 LIBR. ASS'N REC. 174 (1984).
} 
In the fourth step the consultant presents the written findings and proposed plan to the client. It is most likely that the information gathered in step two will refute the findings in step one, or at least cause a modification of the initial plan. The final plan reflects any agreed upon modifications, includes specific timetables for deliverables, and clearly lists the duties and responsibilities of all parties. The goal is to eliminate any ambiguity that could result in misunderstandings or unfulfilled expectations.

In summary, consultant work, often described and documented in the language of project management, gives the appearance of straightforward linear start-to-end work. However the human element can quickly derail a project if it is not invited into and incorporated into the project. Clear and detailed documentation reduces ambiguity, captures the human element and works to ensure the successful resolution the client and consultant both strive toward.

\section{Staying on Task}

Depending on the nature of the arrangement, the consultant's work may conclude with the development and delivery of the recommendations. Alternatively, the consultant may stay involved, perhaps even onsite, to guide the implementation of the recommendations (i.e., bring the project to completion). One of the most challenging aspects of this step is for the consultant to stay on task; that is to adhere to the plan. Managers and administrators used to working with their own employees often want to exercise an "other duties as assigned" concept with consultants. Failure to exercise the "just say no" option too often will undoubtedly cause the demise of the project timeline.

During this stage, reports are prepared and delivered per the project timetable. The initial report will be replaced with time specified sequential interim reports. The interim reports serve a variety of purposes. First, the interim reports document the work that has been completed and identify in writing any problems that arise that may delay implementation. Second, the interim reports prepare the client for what is coming next. Third, there is certain validation that the client is receiving their money's worth, that is, progress is being made. Last, and most importantly, these reports serve as communication devices that cannot be ignored, misplaced, or left unread without consequences.

\section{E. Concluding the Relationship}

The final written report presents the client with a synopsis of the entire project including the results obtained. ${ }^{27}$ The report is also an opportunity to outline and document any remaining going forward guidance and advice with

\footnotetext{
${ }^{27}$ Stryker, supra note 6, at 154.
} 
respect to completing aspects of the project that extend out beyond the date of the consultancy (e.g., data collection at future points; employee reviews; or hiring new staff). The report also operates as a means of transmitting the consultant's insights and recommendations about how the organization can more effectively operate in the future. Stryker advocates that this closure document enables the organization to internalize the consulting process and use it as a model for resolving future organizational issues. In short, the organization evolves to become its own consultant. ${ }^{28}$

\section{F. Project Management versus Change Management}

As change leaders, consultants function on two levels when called into an institution to solve a problem. On one level-the technical level-the consultant is charged with devising and implementing a solution to a problem. On the other level - the human level - the consultant seeks to successfully implement meaningful change to ensure that the problem stays solved. Therefore, a successful consultant will need to possess both the technical and human strategy skills to bring about the needed change.

Although the consultant manages the two levels in tandem, each level requires a very different approach and skill set. The previous sections of this article conceptualize and detail the technical level of a consultant's work as a project management process. Although it is logical to view and understand the technical work of a consultant in this framework, the project management framework does not capture "how" the work is accomplished. To understand how the work is accomplished, the human level, we need to use a change management framework. Kouzes and Posner's five exemplary leadership behaviors provide the needed change management framework. ${ }^{29}$

Kouzes and Posner advocate that "behavior" is the key to successful change leadership. From their research results they have identified five exemplary leadership behaviors employed by successful leaders:

- Inspire a Shared Vision

- Model the Way

- Challenge the Process

- Enable Others to Act

- Encourage the Heart ${ }^{30}$

The following is a brief introduction and explanation of these leadership behaviors in the consultant context.

${ }^{28}$ Stryker, supra note 6, at 169.

${ }^{29}$ JAMES M. KOUZES \& BARRY Z. POSNER, THE LEADERSHIP CHALLENGE (4th ed. 2007).

${ }^{30} \mathrm{Id}$. at 15. 
In Kouzes and Posner's framework, success comes when change leaders "model the way." A consultant must engage in behavior that signals the work being done is meaningful and important to the success of the project. The actions of the consultant are more important than words or speeches in establishing the common goal and validating the importance of the work to be accomplished. A successful consultant will set an example by engaging in the actual work; these actions validate that the work is important and meaningful. Put simply, be part of the team and don't ask anyone to do something you yourself would not do. ${ }^{31}$

Everyone working on the project must be interested in and inspired by the promise of the something better that will result at the conclusion of the project. This requires that the consultant successfully develops and conveys a shared goal or shared vision of what could be. Inspiring a shared vision requires that the consultant have enthusiasm for and true interest in the success of the project. His or her commitment to the project must then be conveyed to the others in terms and in a manner that resonates with each individual team member. Without this, the team will not be able to envision or be excited by the possibilities associated with proposed change, and in turn will not be committed to following through and successfully completing the project. ${ }^{32}$

Resolution of a problem requires a challenge to the existing way the institution operates. ${ }^{33}$ Problem-solving consultants challenge the process because they are changing the status quo. Challenging the status quo may require that a process or procedure is evaluated at each step. That is, not only must the change itself be seen as a challenge to the existing status quo, but each step in reaching the desired change presents an opportunity to evaluate and reinvent. Envisioning the process in this manner also allows for better planning and provides opportunities for modification at each step.

Successful projects more often result from a "we" than an "I" attitude. A successful consultant recognizes that his or her greatest asset is the individuals doing the work, i.e., implementing the solution. As the leader it is his or her job to create the environment that enables these individuals to do good work and to "strengthen [their] capacity to deliver on the promises they make."34 In sum, successful projects result from collaboration and a sense of ownership; this happens when it is a "we" project and individuals are vested in the project's success.

Solving a problem is often a long, complicated, and even tiring process. Restarts, rethinks, and delays can cause frustration and loss of interest. At these points, it is the role of the consultant as change leader to encourage everyone to

\footnotetext{
${ }^{31}$ Id. at 16.

${ }^{32}$ Id. at $17-18$.

${ }^{33}$ Id. at $18-19$

${ }^{34} \mathrm{Id}$. at 21.
} 
hang in there. Consultants do this by recognizing contributions and showing appreciation in an authentic manner. "Encouraging the heart" creates a sense of collective identity and community that can carry the group through both the good and hard times. ${ }^{36}$

Consultants as change leaders need to be both technical and human strategists to achieve the desired result for their clients. This requires not only researching and developing the best solution but developing a relationship with each of the individuals that will be part of the team implementing the solution. Incorporating Kouzes \& Posner's five exemplary leadership behaviors to build and sustain these relationships provides an effective strategy to use to ensure a successful result.

\section{Part II. Theory to Practice: A South Africa Case Study}

\section{A. Background Information}

The Legal Resources Centre, South Africa's largest and oldest national public interest law organization (the "LRC"), was organized in 1979 to challenge apartheid in South Africa's courts. ${ }^{37}$ As South Africa moved past apartheid to a constitutional democracy, LRC lawyers played a significant role in drafting the new South African Constitution and crafting a legal framework for the emerging democracy. In 1994, then President Nelson Mandela appointed an LRC founding member, Arthur Chaskalson, ${ }^{38}$ to serve as the first President of South Africa's Constitutional Court.

Today the LRC employs more than 65 lawyers and staff at four separate offices: a National Office that includes the Constitutional Law Unit in Johannesburg and three other law offices located in the cities of Cape Town, Durban, and Grahamstown. The LRC advances research and provides free legal services in the areas of land and housing rights, children's rights and education, environ-

\footnotetext{
${ }^{35}$ Id. at $21-22$.

${ }^{36} \mathrm{Id}$. at 23.

${ }^{37}$ See generally Legal Resources Centre of South Africa (Jun. 25, 2014, 11:00 AM), http://www.Irc.za.org.

${ }^{38}$ Arthur Chaskalson (1931-2012) was a leading South African constitutional jurist and human rights lawyer. In 1963, he was a member of the legal defense team for the defendants at the Rivonia Trial as well as other important anti-apartheid trials. Chaskalson helped establish the LRC, and served as the LRC's director from 1978 to 1993. See biographical information at South Africa History Online (Jul. 31, 2014, 9:00 PM), http://www.sahistory.org.za/people/chief-justice-arthur-chaskalson.
} 
mental justice, HIV/AIDS, health and other social services, refugee matters, and women's equality. ${ }^{39}$

The LRC library system includes the main library in the Johannesburg LRC office and three branch facilities in each of the Cape Town, Durban, and Grahamstown LRC offices. All four offices provide a collection of print and electronic resources that includes South African materials as well as a small number of foreign and international resources. The Cape Town library houses a significant archival print collection on South African land reform. In addition, the Johannesburg and Durban libraries house significant historical archival collections of personal papers and legal materials. All four offices maintain their closed legal case files, either onsite or offsite. ${ }^{40}$ Case files associated with matters to be appealed or transferred to the Constitutional Court are transferred from the office handling the matter to the Constitutional Litigation Unit located at the LRC's National Office in Johannesburg.

\section{B. A Modest Proposal}

Despite the important role the law library plays in supporting the work of the LRC, the LRC library system was in disarray in 2012. Arthur Chaskalson recognized the importance of a modern law library that would support the work of the LRC, and as a result sought help addressing and solving the library's issues so that it could more effectively support LRC's legal work and research efforts.

In 2012, the LRC approached the Southern African Legal Services Foundation ("SALS") ${ }^{41}$ for assistance in assessing and modernizing the LRC's library system. SALS formed an ad hoc library committee to provide technical

\footnotetext{
${ }^{39}$ See generally Legal Resources Centre of South Africa (Jun. 25, 2014, 11:00 AM), http://www.lrc.za.org.

${ }^{40}$ The closed case files are relevant because the work of organizing and managing these files was in the current LRC law librarian's job description. Case files from the closed Pretoria office were also brought to the Johannesburg office for processing.

41 "The Southern Africa Legal Services Foundation (SALS) is a U.S. § 501(c)(3) charitable organization based in Washington, D.C., which was founded in 1979 by Lloyd Cutler, Erwin Griswold, Louis Loss, and Bernard Segal. They decided to found SALS after leaming that ... distinguished members of the South African Bar intended to establish what would become the ... LRC during the height of apartheid. It was the hope of these four Americans that the establishment of SALS and its relationship with the LRC might offer some level of protection to LRC lawyers and staff during those dangerous days." See generally The Southern Africa Legal Services Foundation (Aug. 1, 2014, 11:00 AM), http://www.sals.org.
} 
expertise and agreed to provide financial assistance. ${ }^{42}$. The committee contacted Barbara Bintliff, Director of the Tarlton Law Library/Jamail Center for Legal Research and the Joseph C. Hutcheson Professor in Law, at the University of Texas School of Law in Austin, to make a preliminary assessment of the LRC's law libraries. In late 2012, Professor Bintliff traveled to South Africa and spent four days onsite in Johannesburg and Cape Town. Based on her initial assessment, the LRC sought an experienced law librarian who would assist it in developing, organizing, and implementing plans to create a modern and professional law library to support the LRC's lawyers and researchers. In September 2013, the LRC retained the author as a Senior Fellow to assist in modernizing the LRC library system. I was onsite in Johannesburg for six months, from September 2013 to April 2014. The following discussion focuses on my efforts to respond to the modest proposal to create a modern, efficient, and most importantly relevant law library for the LRC organization.

\section{The Challenge}

The LRC library was in disarray for a number of reasons, including issues with physical space, intermingling of non-library materials, intermingling of archival materials, collection management, staffing and organizational culture, and technological infrastructure. Each of these reasons is more fully discussed below:

Space. The LRC national office relocated to its current office space on the 15th and 16th floors of the Bram Fischer Towers on Albert Street in 2010. Prior to the move, the LRC's law librarian had left the LRC to take another position. The law librarian position was not filled until late 2011. Consequently, the relocation of the library was not supervised by a librarian. The new office space resulted in greatly reduced space for the law library. As a means of compensating for the reduced space, library materials were stored one floor down in the board room. As of 2013, many of the library materials had not yet been unpacked and were stored in various storage places throughout the 16-floor office building. In addition, the library furniture had been repurposed for use in the offices.

The Cape Town office had likewise experienced a move and the library collection was housed in both the board room and the library. There also

${ }^{42}$ The SALS board members comprising the ad hoc committee were Reuben G. Clark II, chair, Harvey Dale, and Evan Lieberman. Mr. Clark, SALS President and Secretary, is a partner at the law firm of Williams Mullen, P.A. Professor Dale is University Professor of Philanthropy and the Law and the Director of the National Center on Philanthropy and the Law at New York University. Professor Lieberman, is an Associate Professor of Politics, and Associate Chair of the Department of Politics at Princeton University. 
appeared to be little rationale for what was stored in the libraries and what was stored in other places in the offices. The Durban and Grahamstown libraries suffered from overcrowding and lack of space. In Grahamstown, the library is housed entirely in the main and only conference room. In Durban, Cape Town, and Grahamstown the library is also used as working spaces for short-term interns. In short, none of the libraries offered welcoming spaces conducive to research and study.

Intermingling of non-library materials. The physical state of the libraries also reflected a general lack of records management. Case files and lawyer duty files were often left unprocessed/closed in offices after the departure of interns and lawyers. Case files and lawyer files were also often stored in any available space until the files were processed and closed. The libraries unfortunately represented untapped space in "space-challenged" offices. As a result, stacks and/or boxes of paper were simply put in the library when the office was repurposed for a new attorney or researcher. Since records management fell within the job description of the law librarian, it was assumed to be "okay" to just put paper in the library for her to deal with at some point in time. The lack of full-time librarians in three of the offices to "guard" the library space had led to the libraries serving as on-site storage for unwanted and abandoned or unprocessed materials. ${ }^{43}$

The libraries also tended to be the resting place for any grey literature that was sent to the LRC (e.g., government reports and mailings, NGO annual reports and newsletters). These materials were not catalogued and often not relevant but tended to stack up in the libraries.

Last, the CapeTown and Durban libraries still continued to maintain large print clipping files.

Intermingling of archival materials. Materials reflective of the rich and historically important history of the LRC were also intermingled in the library's working collection. For example, the founders of the LRC contributed their personal law libraries to the LRC. In addition, the Bram Fischer collection which includes the law libraries of both his father, Percy Ulrich Fischer, a Judge President of the Orange Free State, and grandfather, Abraham Fischer, a prime minister of the Orange River Colony, and a cabinet member of the unified South Africa as well as Bram Fischer's own law books was given by the Fischer family to the LRC. This three generation family library included both primary and secondary sources and spanned the years from the 1700's to the 1950's. The collection was managed and cared for by Arthur Chaskalson while Bram Fischer was in prison for his anti-apartheid activity. In addition, Arthur Chaskalson and

${ }^{43}$ For example, the Cape Towr library was housing an entire wall of operating records belonging to an agricultural NGO that had closed its offices nearly a decade ago. These records were discarded in the process of reorganizing and cleaning up the library. 
other Constitutional Court judges had donated legal materials over the years. Much of this material was fragile and in need of archival care and preservation.

In addition to legal materials, important archival papers of the LRC organization and important persons associated with the LRC were also in the care of the library. For example, the personal papers of George Bizos, a South African human rights lawyer who represented Walter Sisulu, Nelson Mandela, as well as the families of Steve Biko, Chris Hani, and the Cradock Four. ${ }^{44}$ Bizos is still an active member of the LRC legal staff.

Collection Management. The law library maintains both print and electronic resources with the goal of moving to a significantly more robust electronic resource collection. The core print collection consisting of select journals and case reporters was sound in each of the libraries. However, much of the monograph collection and journal collection was out of date and in need of weeding. None of the libraries maintained a current catalog of its materials. New monographs were housed by topic, but the topics were not consistent across all four libraries. This limited the ability to share materials among the libraries.

In addition, the transition from print to electronic of many research resources had not been acknowledged and implemented in the Cape Town, Durban, and Grahamstown libraries. This caused a variety of problems, including (i) retention of out-of-date and obsolete materials that took up valuable space on library shelves; and (ii) duplicate purchasing in print format of materials that were available in the subscription databases. Further, inadequate staffing in these libraries resulted in the failure to properly update and maintain valuable and expensive print resource, rendering them useless.

Staffing and organizational structure. The LRC libraries employed only one full-time law librarian. In addition to responding to research requests from all four libraries, this individual was charged with certain overall administrative responsibility for the other libraries. Despite this charge, the Cape Town, Durban, and Grahamstown libraries routinely resisted efforts to be managed by the National Office. This is perhaps in part due to the historical structure of the organization. ${ }^{45}$ For example, the branch libraries routinely purchased duplicative print materials and often declined shared collection proposals and cancelled training sessions.

Last and most importantly, there was a lack of understanding of the purpose and role of the library in the organization. There was overwhelming

\footnotetext{
${ }^{44}$ See biographical information at South Africa History Online (Jul. 31, 2014, 9:00 PM), http://www.sahistory.org.za/people/george-bizos.

${ }^{45}$ The LRC's organizational structure was specifically designed to survive efforts by the apartheid government to shutter the organization. As such, each office was designed to function independently in the event the apartheid government was able to close one or more offices. Today, the remnants of this organizational structure challenge the ability of the LRC to function cohesively as a single-minded entity.
} 
praise from all four offices for the quality of research and timeliness of the response to research queries by the law librarian. However, this respect did not translate at the national organizational level. Some examples of this condition include: (i) the lack of authentic involvement of the law librarian in the budget process; (ii) the salary the law librarian received as compared to the level of responsibilities; (iii) statements that reflected a lack of understanding of the importance of research versus searching the internet; (iv) a lack of interest in understanding library concepts, such as the difference of cataloguing versus inventory; (v) a lack of respect for the role of the law librarian; and (vi) the failure to recognize the imperative to provide adequate print and electronic resources.

Technological infrastructure. The LRC and by extension, the libraries suffered from the lack of stable and robust internet access. At one point during the six month period, the National Office lost all wired internet access for a period of nearly two weeks and used pre-purchased $3 \mathrm{G}$ access for the entire office.

In summary, the libraries were challenged physically and philosophically. The overcrowding, absence of current and relevant resources, and lack of organization did not create an environment conducive to research and studying. In addition, the lack of understanding of the purpose of the library and its importance in supporting and advancing the work of the LRC resulted in an underfunded, understaffed, and undervalued library. These circumstances created the need for an outside consultant to be onsite to assist the LRC in developing, organizing, and implementing plans to create a modern, efficient and professional law library to support the work of the LRC's lawyers and researchers.

\section{The Approach}

The approach used was a combination of project management and change leadership utilizing the Kouzes and Posner change leader behaviors. ${ }^{46}$ Upon arrival at the LRC, the first step at the National Office was to unearth the law library and reclaim the physical space for library purposes. The goal was to provide as quickly as possible some glimmer of what the library could be in order to inspire a shared vision. As a result, excess shelving that was blocking windows was dismantled and stored, the print collection was dramatically weeded and materials discarded, archival materials were boxed up and moved to the $12^{\text {th }}$ floor for processing, operational papers and case files were processed and incorporated into a newly created system, and the non-library materials,

${ }^{46}$ As noted earlier, these behaviors include the need to: inspire a shared vision, model the way, challenge the process, enable others to act, and encourage the heart. 
including a tennis table, were removed from the library. Each of these projects involved modeling the way. No work was considered beneath my pay grade. I personally hauled dumpsters down sixteen floors to the parking garage, filed papers into case files, labeled and hauled boxes to storage, cleaned shelves, tied up bundles of books, and muscled shelving units across the library with the law librarian and a part-time worker.

Library tables and chairs were reclaimed and positioned with artwork in the prepared space in the library. The South African portion of the Bram Fischer collection was reorganized and showcased in this area. Creating this airy, welllit, and calm space inspired a vision for the rest of the library. Lawyers and staff visited the library, many for the first time, and were enthusiastic about the space and expressed a reverence for the Bram Fischer collection. ${ }^{47}$ The lawyers and staff soon made requests for new soft seating and an espresso machine. Unfortunately these were not in the budget, but it was heartening to see that they were now vested in their library.

Equally important was encouraging and enabling members of the LRC staff to carry out the work. The law librarian was overwhelmed given that she was responsible for both managing the library and serving as the information officer charged with records management. In such circumstances it is easy to come in from the outside and look like a hero. The law librarian was providing outstanding reference and research assistance to the lawyers and researchers. There just weren't enough hours in the day to deal with the library's physical space, collection management, and other needs. As such it was important to validate her contributions as we worked on the collection, space, and other issues. In addition, after coming to recognize the efficiencies that arise out of information govemance, other members of the LRC staff participated in the development and use of a fledging information management system.

As the outside consultant, it was also easier for me to challenge a number of processes. For example, recommending that regional offices no longer be allowed to purchase library materials by moving all budgeting and purchasing to the National Office. Similarly, it soon became clear that I was going to hold the line at commonly accepted practices that didn't benefit the library (e.g., the ongoing use of the library as a place of storage). LRC staff soon stopped coming by to ask if the communication department or development office materials could be stored in the library. This in turn led to my volunteering to help organize other spaces in the office.

${ }^{47}$ Similar actions were taken at the Cape Town and Grahamstown libraries. At the end of six months, three of the four libraries were ready to move to the next phase. The Durban office employed a part-time librarian that was independently working on the project in the Durban library. 
Additional work of assessing and reorganizing the monograph and journal collection, developing a library budget, inventorying historical materials for insurance and valuation purposes, creating signage, and moving additional furniture was also done. At the National Office (and the Cape Town office), decisions were made with respect to what materials were to be housed in the respective board room. In both offices the need to use shelving in the board room was significantly reduced after the completion of the weeding. At the National Office, the board room shelving included glass fronted locked cabinets that were repurposed to showcase the valuable materials in the Bram Fischer collection.

Steps were also taken to better understand and address technological infrastructure issues. Meetings were held with TENET: The Tertiary Education and Research Network of South Africa ("TENET") would be able to join the program.

At the same time, a philosophical and cultural assessment was made of the libraries. The visits included meetings and conversations with all relevant stakeholders, including attorneys, paralegals, interns, researchers, librarians, and management. These conversations led to a number of recommendations that are described below.

\section{E. Recommendations}

At the end of the six month period, specific detailed recommendations were made to the LRC with respect to the libraries. In addition to the recommendations, documented support for the recommendations and advice on how best to implement the recommendations was provided in written format to the LRC. An executive summary of some of the recommendations follows below:

- Split the library and knowledge governance functions into two positions;

- Employ a law library director that manages all four libraries and administers the budget and all library purchases at a national level who is organizationally empowered to carry out the functions of the library (i.e., collection development and management, training, space planning, research services);

- Employ a knowledge governance/records management officer;

- Seek funding for the proposed library budget;

- Move from print to electronic resources and provide on-going training for all staff;

- Adopt and implement a shared online cataloging system;

48 TENET is an NGO. Its main purpose is to provide, for the benefit of South African universities and associated research and support institutions, internet and information technology services. 
- Adopt an archival policy that provides for the valuation and safe keeping of the archival materials (i.e., the LRC historical papers, the Bram Fischer and other legal materials, case files, and important persons papers); and

- Continue to explore options for a more robust and stable internet provider.

Consulting in any environment is challenging. It is even more so in an international setting where one must carefully navigate cultural norms. Was pulling dumpsters, muscling shelves, and other physical labor acceptable for me to do? There were some raised eyebrows, but in the end it was worth it. It is also important to remember to measure success by the standards you are operating in, and not by western standards. In six months, a lot was accomplished. Not everything, but enough to set the stage for the LRC to move forward. In the summer of 2014, the LRC took steps to fill both the newly created law librarian and knowledge governance/records management officer position. These are the important first steps in continuing to maintain and move the LRC libraries forward.

\section{Part III. Librarian as Consultant}

\section{A. Librarians as Consultants}

Librarians are natural consultants, possessing both the technical expertise and the requisite change management skills. Green and Morris vehemently dismiss the need for libraries to retain consultants and advocate that libraries look inward for the needed expertise. ${ }^{49}$ Similarly, Kasper and vanDuinkerken note that there are "some organizations which are more likely to have internal consultants; these would be organizations that face change and evolve, empower and grow their employees as opposed to keeping them in boxes (because by definition, an internal consultant is an out of box actor), and are flexible and want to make the best use of their internal resources." observing any organization it is easy to identify those certain individuals who are tagged to implement new programs and services, in other words the "internal consultant." ${ }^{.51}$ Tying their research directly to libraries and librarians, Kasper and vanDuinkerken find that librarians possess the same skills and motivations as consultants. ${ }^{52}$ More recently, Wilson advocates that the work of library liaisons

${ }^{49}$ Green, supra note 15, at 133; Leslie A. Morris, Library Consultants: An Editorial, 14 J. INTERLIBRARY LOAN, DOCUMENT DELIVERY \& INFORMATION SUPPLY 1 (2003).

\footnotetext{
${ }^{50}$ Kasper \& vanDuinkerken, supra note 5, at 1.

${ }^{51} \mathrm{Id}$.

${ }^{52} \mathrm{Id}$.
} 
is similar to a "business consultant's role in analyzing and advising." message is clear: librarians can capably manage consulting opportunities.

If the "best way for libraries to succeed in today's work environment is by making the most of their internal consultants" ${ }^{34}$ and all that librarians need to fulfill this role "is a healthy dose of self-confidence," should we be looking for on a librarian's resume? Wormell, Olesen, and Mikulás identified the following as skills a consultant should develop: concentration, multi-tasking, patience, equanimity, quick study, communication, relationship management, ability to project credibility and gain trust, negotiation, tolerance and ambiguity, corporate culture savvy, and independence. ${ }^{56}$ Additional survey research conducted by these researchers of organizations utilizing consultants identified the top five client preferred characteristics: professionalism, communication skills, goal-oriented, creativity and problem solving capability, and adherence to schedules. ${ }^{57}$ Last, the following top ten attributes were identified in a survey in which the Independent Consultant Association asked its members to describe the "ideal" consultant:

- Knows how to methodically diagnose any problem, structure, or organization.

- Is constantly learning and growing.

- Never misses a deadline.

- Can prepare a compelling report with clear, helpful graphics.

- Knows how to tap the right and left sides of the brain.

- Loves the client and becomes a true friend.

- Understands how to use leverage for clients as well as in the consultant's practice.

- Is technologically competent.

- Knows how to participate in a meeting with equal effectiveness.

- Knows what's going on in the world and is generally well read. ${ }^{58}$

Although these skills may vary by the nature of the work, successful consultants need to possess change management and leadership skills as well as technical skills.

${ }^{52}$ Id. (2013)

${ }^{53}$ E. Michael Wilson, The Role of Library Liaison as Consultant, 77 KY. LIBR. 14

${ }^{54}$ Kasper \& vanDuinkerken, supra note 5, at 2.

${ }^{55}$ Green, supra note 15 at 135.

${ }^{56}$ Wormell, Olesen \& Mikulás, supra note 13 , at 28-29.

${ }^{57}$ Wormell, Olesen \& Mikulás, supra note 13, at 136-137.

${ }^{58}$ Elaine Biech, The Business of Consulting, The Bastcs AND BEyond 2d 31 (2007). 


\section{B. Why Take on the Role of Consultant?}

In this economic climate, librarians with the right competencies and skills are likely to be approached either for an intemal project or an external service opportunity. If approached for such an opportunity, you might ask yourself "why should I?" There are a number of very good reasons to say "yes." First, such an invitation validates your competency in a specific area and creates an opportunity to build your resume because you are applying your skills in a different setting. Second these opportunities allow you to focus on a specific and often narrow project in a way that may even further develop your skills or interests in the area. Third, it is often an opportunity for those in middle management to gain additional management experience. Fourth, there is the simple sense of pride and satisfaction from helping out and doing good work by "fixing something." And last, depending on the circumstances, it might be a project outside the usual workplace politics that will allow you to call your own.

\section{Conclusion}

Consultants are retained to assist libraries in identifying, designing, and implementing solutions to a wide variety of strategic, management, operational, and human resources issues. The goal of the library-consultant relationship is to improve the operations of the organization. Although often unrecognized as such, law librarians are natural consultants. Opportunities exist for those versatile librarians skilled in change management and interested in pursuing these challenging professional opportunities. ${ }^{59}$

${ }^{59}$ Additional extemporaneous writing about the author's experiences in South Africa is also found on her blog, rightangleresume (www.rightangleresume.blog-spot.com). 